\title{
The Implication of Covid-19 on Educational Disparity Between the Developed and the Developing Countries, Urban and Rural Dwellers and, on ICT in Nigeria
}

\author{
Daniel, Orifamah Ph.D \\ Department of Physical Science Education, Imo State University, Owerri
}

\begin{abstract}
Education as an agent of socialization started in Iraq located in Asia and later in Egypt located in Africa and proceeded to the European countries where it grew and overshadowed that of the originators in Asia and in Africa through industrial revolution in Europe which became intensely magnified with the development of the computers leading to information and communication technology (ICT), though, the application of ICT to education had been Known for many decades, its overwhelming significance has not come to bare as it is today with the rise of Covid19 pandemic, the researcher therefore set out to investigate: the implication of: covid-19 on educational disparity between the developed and the developing countries, urban and rural dwellers, the rich and the poor, and on Information and Communication Technology (ICT) using an open-ended survey questionnaire and found out that: the onset of Covid-19 unfolds the latent potentials and significance of ICT which will further widen the educational gaps between the developed and the developing countries, the urban and rural dweller, the rich and the poor, especially in Nigeria and in Africa as a whole, in the light of the above findings the researcher recommended among others that Nigeria should improve on internet connectivity and electricity, provide ICT devices for learners, and above all provides free e-learning educational site(s) for all categories of learners
\end{abstract}

Keywords: Implication, Covid-19, Disparity, Developed, Developing, Urban, Rural, ICT.

DOI: $10.7176 / \mathrm{JEP} / 12-30-06$

Publication date:October $31^{\text {st }} 2021$

\section{Introduction}

Education as an agent of civilization and socialization has its foundation in Mesopotamia (Iraq) in Asia and was later taken over by Egypt in Africa (https://www.history.net). From Egypt, civilization moved through Harappa in India to Europe. Modern civilization however may be traced to Europe which started in the form of the industrial revolution in Britain in the $18^{\text {th }}$ century (https://www.britannica.com). This was amplified by the invention of computers leading to the formation of information and communication technology (ICT). The invention of the computer has had a tremendous increase in knowledge mostly in the western world vested with the technology of the computer and its artificial intelligence because of the artificial intelligence of the computer finding its significance in all spheres of life education not left out. Education therefore in the western world is a large gap from that of the developing or third world countries that depend on developed countries for the computer and its processes.

\section{Meaning of Covid-19}

Covid-19 is a coronary virus heart infection that has the potential to block partially or completely the coronary artery carrying blood to the heart, the figure 19 (nineteen) attached to the word Covid indicates the year such infection occurred at an epidemic level. Medically, it means a coronavirus infection which surfaced in 2019 and therefore is called 2019 new or novel coronavirus or " 2019 nCoV" where ' $n$ ' stands for new or novel, 'Co' stands for corona and ' $\mathrm{V}$ ' for a virus (https://www.medicalnewstoday.com)

There is also the concept that Coronaviruses are named to reflect their appearance which shows a clear spike with chubby tips that beautify their surfaces, which called to mind of the virologists the appearance of the sun's atmosphere referred to as its corona, (www.the-scientist.com)

\section{Origin of Covid-19}

There are divergent views about the origin of covid-19. According to Aaron (2020), it is likely a new form of a natural coronavirus that originated from bats or pangolins and whose first transmission to humans was in Wuhan a town located in China, and which its further transmission after the first human infection was from person to person body contact. That is, Conaviruses are types of viruses that can infect humans, an example of which is the "Severe Acute Respiratory Syndrome (SARS) which occurred in 2002 - 2003: the origin of which was also traceable to China.

\section{CONTROL MEASURES TO COVID-19 AND IMPLICATIONS}

Covid-19 has been a viral infection, in addition to the presence of a clear spike with rounded tips that beautify their 
surface consisting of protein making it not easily detectable by the White blood cells, stood strong against any direct treatment except side effects and control measures employed to limit its spread. The control measures adopted include among others masking nose/mouth, closedown of borders to a total lockdown which kept everyone indoors bringing the economy of the entire world to a halt. Teaching and learning were not left out as a complete lockup of all human race - in the presence or absence of food became the most potent control measures to the geometrically ravaging covid-19 pandemic.

\section{E-LEARNING AND COVID-19}

Covid-19 halted all or almost all the industrial activities in the world except the education sector which was fully relocated to online mode in the developed world, Mohammed (2020). The history of e-learning contrary to a novel technology as many learners would say maybe traced to 1924 when Professor Sydney of Ohio State University invented the technology called "Testing Machine" to 1954 when Professor B. F. Skinner of Harvard University came out with another technology called "Teaching Machine" through 1960 when Plato came out with the first Computer Based Training (CBT), gradually to the present day where new electronic and computerized learning processes has gathered momentum been influenced by the social media using various platforms such as You-tube, Twitters, WhatsApp, etc., Ruparel (2021). Though, the term e-learning came up in about 1999 to seemingly replace other terms that were previously used such as online and virtual learning, Ruparel (2021). E-learning is a component of Information and Communication Technology (ICT) and therefore demands ICT resources such as the computer, the scanner, the projector, the video camera, the printer, the television, the radio, the teleconferencing device, and so on. In addition, all items useful to ICT depend on electricity which is generally epileptic in Nigeria. Therefore, the issue of e-learning in Nigeria is mostly in theory as the internet connectivity (another major component of ICT) in Nigeria is also epileptic, and the available electric light to power the various devices is poor. This issue of electric light to power the various devices further cripples the possibility of ICT usage in locations where internet connectivity is available. As a result of these setbacks Schools like the "National Open University of Nigeria" (NOUN) make use of special textbooks called "Modules" specially authored by specialists in each course of study and take examinations in special centers.

Resulting from the above, in a time of state emergency just as it were in the Corvid-19 pandemic when the developed world quickly drifted her education curriculum to online, (Mohammed 2020) most other parts of the world including Nigeria completely shut down her education sector just like any other commercial or economic sectors, a situation that would widen the existing educational gap between the developed world and developing countries like Nigeria.

Therefore, the purpose of this investigation was to find out: the implication of covid-19 on the educational disparity between;

1. the developed and the developing countries,

2. the urban and rural dwellers,

3. the rich and the poor, and

4. Nigeria preparedness for future emergencies with information and communication technology (ICT)

\section{Design and Procedures:}

The design of this investigation was a survey research design having a population of 19,567 comprising of all the students in Delta State University of Science and Technology Ozoro, in addition to all the Teaching staff in the primary and secondary schools in Isoko North and South Local Government Area (LGA) respectively, of Delta State. The sample for the investigation comprises of three hundred respondents taken from the population above: one hundred respondents (undergraduates students only), one hundred respondents from the primary school teachers in Isoko North, and one hundred respondents from the secondary school teachers in Isoko South.

\section{The instrument for data collection}

The main instrument used to elicit responses from the respondents for this research was an open-ended survey questionnaire designed by the researcher and appropriately validated, containing twenty-nine (29) items subdivided into five sections. Section one was on the respondents'" demography, section two was structured to elicit a response on the implication of covid-19 on the educational disparity between the developed and the developing countries, section three was structured to elicit a response on the implication of covid-19 on the educational disparity between the urban and the rural dwellers, section four was structured to elicit a response on the implication of covid-19 on the educational disparity between the rich and the poor, and section five was structured to elicit a response on the Nigeria preparedness for a future crisis with information and communication technology (ICT). 


\section{SURVEY FINDINGS}

The implication of covid-19 on the educational disparity between the developed and the developing countries From the survey, 54\% (162 respondents) from the 300 respondents have their schools located in urban areas this population includes 100 undergraduates in addition to 40 secondary school teachers and 22 primary school teachers from Isoko South and Isoko North respectively. Among these 300 respondents, though all considered the pandemic a great threat to education in Nigeria, only 63 undergraduate respondents equivalent to $21 \%$ of all the respondents' listed education as being among the most commonly used ICT (at least weekly) making and receiving calls not inclusive. In addition, when all the respondents from primary and secondary schools reported the state of ICT devices as far below average the undergraduates report the same as average, but, on the whole, all the respondents reported a continuous widening of the educational gap between Nigeria and the developed world on the absence of argent attention to technology. Responding to "how have the State or Federal Government-assisted teaching and learning during the covid-19 crisis? 78 undergraduates' respondents remained anonymous, while the remaining twenty-two (22) undergraduate respondents reported feeding primary school pupils without details as to how and where when the schools were not in section. Contrarily, 144 respondents from the primary and secondary schools reported fumigation and clearing of the school compounds in addition to the provision of face masks, hand washing buckets, and sanitizers to the schools on school resumption. Three (3) of these respondents, added provision of 500-liter tank without consideration for a borehole to get portable water, while the remaining 56 respondents from the primary and secondary schools reported ( 20 from the primary and 36 from the secondary) e-learning classes for certificate classes: primary 6, primary 9 (Junior Secondary School 3), and Senior Secondary School 3. No detail was also given as to mode and time for the program such as through YouTube, Television, Radio, and so on

The Effects of Covid-19 on: Education in the urban and rural dwellers and its Implications for the Use of Technology.

The survey finding showed that most of the rural areas are still cut out of ICT with the 148 rural respondents reported that phone calls are not always guaranteed and another respondent in the urban areas submitted that network connectivity depends on the internet provider (IP) at each point in time as connectivity varies. In addition, the survey showed that IPs with better connectivity cost more to acquire data. The issue of power supply is another obstacle as all the 148 rural respondents complained of a complete lack of public power light throughout the year. On the whole, all the respondents agreed that rural dwellers would be more disadvantaged if ICT is introduced into the Nigerian education system without improvement to a power supply and internet connectivity.

\section{Implication between the rich and the poor learners}

Survey on the education disparity between the rich and the poor learners if e-learning is introduced. All the respondents expressed an imaginable wider gap between the rich and the poor learners resulting from identified three areas, namely: cost of data for internet connectivity, cost of fueling generator for power supply, and the cost of acquiring good ICT devices.

Nigeria preparedness for future crisis concerning: ICT.

On the primary, secondary, and tertiary schools, the state, and the country's preparedness for a future crisis, the 100 primary school respondents reported a lack of technical know-how on their part including lack of ICT laboratories in the schools, on average the 100 primary school respondent genuinely rated themselves less than $20 \%$ on the knowledge of ICT devices. Two respondents from the secondary schools (the same school) reported the presence of ICT laboratory without a computer literate teacher and lack of power source to put them into use, and on the knowledge of ICT devices only three respondents rated themselves up to $40 \%$. The remaining 97 respondents from the secondary schools reported both a lack of ICT devices and knowledge in ICT. From the undergraduates" respondents, only 28\% (28 respondents) reported knowing ICT devices. The entire 300 respondents viewed the transition to e-learning as not realistic complaining of internet connectivity and regular power source, in addition, $63 \%$ of the entire respondents (189 respondents) deemed the cost of acquiring data and probably paying for school website higher than fees to be paid in a face to face teaching and learning. One of the primary school teachers specifically commented that "e-learning was not feasible in Nigeria as power supply and internet connectivity remained a mirage shortly"

\section{DISCUSSION ON FINDING}

The findings clearly showed a lack of government assistance to continue teaching-learning processes during the Covid-19 pandemic except for the certificate classes. These certificate classes consist of only three classes out of twelve classes in the primary and secondary schools equivalent to $25 \%$ of the classes in the primary and secondary schools. This is an indication that there was practically no teaching-learning during the Covid-19 pandemic in Nigeria, contrary to what was obtained in the developed world where the education industry was maintained 
through e-learning, Mohammad (2020). This finding is in line with the survey of the author of EdTech (2020) who contended that schools in Africa were completely shut down as a result of the pandemic. This is an indication of a wider educational gap between the developed and the developing countries like Nigeria

On the Effects of Covid-19 on Education in the urban and rural dwellers and its Implications for the Use of Technology: the discovery showed an expected further educational gap between the urban and rural dwellers if elearning is introduced to replace the face-to-face teaching-learning process. This is because ICT devices including their connectivity are more and better in urban areas. This finding is a contradiction to the work of Byun, and Slavin (2020) who are of the view that the challenges to online teaching-learning processes are reduced because both students and teachers have got the experience and have been interacting with various ICT tools such as mobile-based learning, computer-based learning, and web-based learning. Meanwhile, the study is comparable with that of Arif, Walayat, and Atiq, (2020) who are of the view that even if developing countries will start improving on their ICT tools, it will take not less than ten years to meet up with the present ICT state of the developed world who will not also be static waiting for the developing countries.

The implication of introducing e-learning into education between the rich and the poor learners: the finding from this survey was trite as to widening the educational gap between the poor and the rich. This finding aligns with that of Perrin (2019). Perrin showed that some rural communities are not sufficiently covered by cell phone coverage thereby limiting the chance to cell phone usage and internet connectivity. This finding is also in line with that of Sandra (2020) who opined that the different strategies to continue teaching and learning do not serve all students equally, as they rely on access to unevenly allocated resources for studying at home, such as internet connectivity, electronic devices, space, and parental support. Given this scenario, and with the prolonged shut down of schools, it is feared that the break-in educational continuity and achievement will widen even further between the various family economic statuses.

On the Nigeria preparedness for a future crisis with information and communication technology: the finding showed that a very high percentage of the primary and secondary school teachers surveyed are not ICT literate, their main place of primary assignment also lack ICT laboratories. From the undergraduates respondents: only 28 out of $100(28 \%)$ have ICT knowledge. This is a clear indication of a lack of preparedness for future crises like the covid-19 pandemic.

\section{CONCLUSION}

This research work was on the implication of Covid-19 on Educational Disparity between the Developed and the Developing Countries, Urban and Rural Dwellers and, on ICT. And the finding showed that the covid-19 pandemic has put more demand on ICT because of its eminence significance for educational purposes in form of e-learning thereby widening the educational gap between the Developed and the Developing Countries, Urban and Rural Dwellers, and on ICT. It also showed that if e-learning is introduced the educational gap between the poor and the rich, the rural and urban areas will widen even more. In addition, it showed that there is no iota of preparedness by schools, states, and the nation-Nigeria to withstand future emergencies like the covid-19 pandemic.

\section{SUGGESTIONS}

Sequel to the findings from this survey research, the researcher made the following suggestions:

1. That the government should intensify effort to extend internet infrastructures to the rural areas

2. The government should improve on the state of electricity mostly in the rural areas.

3. The government should start the training of manpower for ICT starting from the primary and secondary schools.

4. The government should establish free e-learning TV sites immediately for all classes in primary and secondary schools.

\section{REFERENCES}

Aaron, K. (2020). Coronavirus cause: origin and how it spread. https://www.medicalnewstoday.com:

Arif, A., Walayat, H., \& Atiq, A. (2011). E-learning closing the digital gap between the developed and the developing countries. Australian Journal of Basic and Applied Sciences. 5(II): 903-908. https://www.researchgate,com

Byun, S. \& Slavin, R. E. (2020).Educational response to covid-19 outbreak in South Korea, Best Evid Chin Education. https://papers.ssm.com > sol3 > papers

EdTech (2020). The Effect of Covid-19 on Education in Africa and its Implications for the Use of Technology. https://www.icde.org > icde-blog $>$ e ...

https://www.history.net. The history of civilization

https://www.britannica.com: industrial revolution

Mohammad, M. (2020). Challenges of e-learning during the Covid-19 pandemic experienced by EFL learners. Arab World English Journal, Vol. II, no.4. 351 - 362. https://dx.doi.org/10.24093/owej/vol. II no 4.23

Perrin, A. (2019). Digital gap between rural and non-rural America persists. https://www.pewresearch.org 
Ruparel, R. (2021). History of e-learning. Retrieved from: filtered.com/blog/post/article/..

Sandra, G..J. (2020). COVID-19 and primary and secondary education: the impact of the crisis and public policy implications for Latin America and the Caribbean: UNDP LAC C19 PDS No. 20. https://www.latinamerican.undp.org

www.the-scientist.com: Origin of Covid-19

\author{
APPENDIX \\ The Survey Questionnaires \\ 1. Title (not compulsory) \\ 2. First Name (not compulsory) \\ 3. Surname (not compulsory) \\ 4. Age \\ 5. Gender \\ 6. Name of school:
}

Implication of: covid-19 on educational disparity between the developed and the developing countries.

7. Do you consider the location of your school as urban or rural environment?

8. What ICT do you use most commonly (at least weekly)? (Multiple answers allowed)

9. What do you mostly use ICT for? (Maximum five responses)

10. How big a danger do you think the COVID-19 pandemic was to teaching and learning in your school?

11. How big a menace do you deem the COVID-19 pandemic to education in the entire Delta State and Nigeria?

12. How has the State or Federal Government-assisted teaching and learning during the covid-19 crisis?

13. Do you consider any negative impact on education resulting from the closure of schools due to the covid-19 crisis?

14. Do you consider schooling in the western world any departure from that in your school under crisis like the covid-19 pandemic? Comment briefly

15. In your opinion, is the state of ICT devices in your school/ country likely to result in a widening of the gap in educational outcomes between developed and developing countries?

The Effects of Covid-19 on Education in the urban and rural dwellers and its Implications for the Use of Technology

16. How do you think about the effects of e-learning during the pandemic?

17. Do you consider any hindrance to the teaching and learning process if e-learning was introduced to your school? If your answer is yes, kindly list not more than four of such hindrances.

18. Do you consider any difference in teaching and learning in the urban and rural dwellers if

e- learning was introduced? If yes to the question above specify some reasons for the likely difference?

Implication between the rich and the poor learners

19. In your school, do you consider any significant obstacle against the poor learners during the COVID-19 pandemic if e-learning was introduced? If any, specify?

20. In your school, do you consider any significant obstacle facing the rich learners during the COVID-19 pandemic, if e-learning was introduced, f any, specify?

21. In your school which group of learners (the poor or the rich) do you think will be most educationally disadvantaged as a result of the pandemics?

22. In your school, what ratio of learners do you feel may be able to access the technology required to enable them learn effectively online, if available?

23. In your opinion, will a move to online learning increase inequality and disadvantage poorer and less economically endowed students?

Preparedness for future crisis (ICT)

24. To what extent do you think your school has adequate ICT devices for future crises?

25 To what extent do you think your co-students/staff have adequate knowledge of ICT devices?

26. To what extent do you think your school can easily transit to distance learning?

27. Please, what kind of additional training / professional development support would find useful for building preparedness to tackle future crises?

28. Rate yourself genuinely on the knowledge of ICT devices, using 1, 2, 3, 4, 5, 6, 7, 8, 9, and 10.

29. In your school, what do you think will be the biggest challenge about using educational technology effectively in a similar crisis? 